\title{
First bryophyte records from Diego Ramírez Archipelago: Changing lenses in long-term socio-ecological research at the southernmost island of the Americas
}

\author{
Primer registro de briófitas en el archipiélago Diego Ramírez: \\ Cambiando los lentes en estudios socio-ecológicos a \\ largo plazo en la isla más austral de América \\ Bernard Goffinet ${ }^{1,2}$, John J. Engel ${ }^{3}$, Matt Von Konrat ${ }^{3}$, Roy Mackenzie ${ }^{2,4}$, Tamara \\ Contador $2,4,5,6$, Sebastián Rosenfeld ${ }^{2,4,7}$, Omar Barroso ${ }^{2,4}$, \& Ricardo Rozzi B $^{2,4,8}$
}

\begin{abstract}
Long-term socio-ecological research requires comprehensive assessments of biodiversity that overcome historical taxonomic biases, such as the strong focus on the vascular flora. This is particularly relevant at high latitudes where the richness of non-vascular plant species exceeds that of vascular species. Additionally, with respect to geographical regions, there is also a marked bias towards ecological and conservation research in the northern hemisphere. In contrast, few studies have investigated patterns of non-vascular species richness in relation to conservation priorities at subAntarctic latitudes, particularly in the sub-Antarctic Magellanic ecoregion. In this work, we contribute to overcome such taxonomic, geographical and ecoregional biases by moving outside these limits, and therefore "changing the lenses" that are commonly used to assess and conserve biodiversity. We implemented these new "biocultural lenses" by including, for the first time, bryophytes in the floristic inventory of the southernmost island of the American continent: Gonzalo Island (56³1'16.8's; 6842'53.5' W) in the Diego Ramírez Archipelago, Chile. The first bryological exploration of the Diego Ramírez archipelago, SW of Cape Horn, revealed a bryophyte flora composed of 14 species, eight liverworts and six mosses. This number of non-vascular plant species almost doubles the eight vascular plants present on the island. Consequently, with our study, we aim to fill a critical gap in the knowledge of the flora of the Diego Ramírez archipelago, and establish an integral floristic characterization
\end{abstract}

for the long-term socio-ecological research and conservation of the southernmost archipelago of South America. Based on the field material collected, the new nomenclatural combination Chiloscyphus secundifolius (Hook. f. \& Taylor)

Department of Ecology and Evolutionary Biology, University of Connecticut, Storrs, CT 06269 USA; https://orcid.org/0000-0002-2754-3895

$\bowtie$ bernard.goffinet@uconn.edu

2 Sub-Antarctic Biocultural Conservation Program, Universidad de Magallanes, Puerto Williams, Chile \& Department of Philosophy and Religion Department of Biological Sciences,

University of North Texas, Denton, TX 76201, USA.

3 The Field Museum, Science and Education, 1400 South Lake Shore Dr., Chicago, IL 60605-2496, USA.

4 Instituto de Ecología y Biodiversidad, Parque Etnobotánico Omora, Puerto Williams, Chile.

5 Laboratorio Wankara de Ecosistemas Antárticos y Subantárticos, Instituto de Ecología y Biodiversidad \& Universidad de Magallanes. Teniente Muñoz 166 Puerto Williams, Chile.

6 Núcleo Milenio de Salmónidos Invasores INVASAL

Laboratorio de Ecosistemas Antárticos y Subantárticos (LEMAS), Universidad de Magallanes, Casilla 113-D, Punta Arenas, Chile.

8 Cary Institute of Ecosystem Sciences, 2801 Sharon Turnpike; P.O. Box AB. Millbrook NY 12545-0129, USA 
J.J.Engel is proposed. The moss flora comprises Amblystegium serpens, a widespread moss, yet hitherto unknown for sub-Antarctic Chile. The bryoflora of Diego Ramírez has its greatest affinities with that of the sub-Antarctic Magellanic ecoregion and Maritime Antarctica. None of the liverworts present on Gonzalo Island occurs on continental Antarctica; in contrast, four of the six mosses are shared between these two areas.

\section{Key words:}

Antarctica, conservation, liverworts, mosses, sub-Antarctic Magellanic ecoregion.

\section{Resumen}

La investigación socio-ecológica a largo plazo requiere evaluaciones exhaustivas de la biodiversidad que eviten sesgos taxonómicos históricos, tales como la restricción del análisis a la flora vascular. Esto es particularmente relevante en latitudes altas donde la riqueza de especies de plantas no-vasculares supera la riqueza de especies vasculares. Otro marcado sesgo en la investigación ecológica y de conservación se refiere a las regiones geográficas, cuyo estudio se ha concentrado en el hemisferio norte. En contraste, existen pocas investigaciones de patrones de riqueza de especies y prioridades de conservación en relación con las latitudes subantárticas, particularmente en la ecorregión subantártica de Magallanes en el sur de Sudamérica. En este trabajo contribuimos a superar los sesgos taxonómicos, geográficos y ecorregionales, moviéndonos fuera de estos límites y, por lo tanto, "cambiando los lentes" que se utilizan usualmente para evaluar y conservar la biodiversidad. Implementamos estos nuevos "lentes bioculturales" al incluir por primera vez a las briófitas en el inventario florístico de la isla más austral del continente americano: la isla Gonzalo (56³1'16,8'S; 6842'53,5'O) del archipiélago Diego Ramírez, Chile. La primera exploración briológica del archipiélago Diego Ramírez, al suroeste de Cabo de Hornos, reveló una flora de briófitas compuesta por 14 especies, ocho hepáticas y seis musgos. Este número de especies no vasculares casi duplica las ocho plantas vasculares presentes en la isla. En consecuencia, con el presente estudio, contribuimos a llenar un vacío de conocimiento crítico sobre la flora del archipiélago
Diego Ramírez y establecemos una caracterización florística integral para la investigación socioecológica a largo plazo y la conservación en el archipiélago más austral de Sudamérica. Sobre la base del material recolectado, se propone la nueva combinación Chiloscyphus secundifolius (Hook. f. \& Taylor) J.J.Engel. La flora de musgos incluye Amblystegium serpens, un musgo de distribución amplia, hasta ahora desconocido para Chile subantártico. Las afinidades de la brioflora de Diego Ramírez se concentran principalmente con aquella de la ecorregión subantártica de Magallanes y la Antártica marítima. Ninguna de las hepáticas presentes en la isla Gonzalo se encuentran en la Antártica continental; en cambio, cuatro de las seis especies de musgos están presentes en ambas áreas.

\section{Palabras clave:}

Antártica, conservación, hepáticas, musgos., ecorregión subantártica de Magallanes,

\section{INTRODUCTION}

The islands of the Southern Ocean are of considerable biological and conservation significance (Chown et al. 1998). We here provide the first-ever report on the bryophytes of Gonzalo Island (Fig. 1A, B) in the Diego Ramírez Archipelago, Chile. The Diego Ramírez archipelago is a group of sub-Antarctic islands (see synopsis of phytogeographical categories in Engel, 1990) situated at the southern end of the South American continental shelf in the Drake Passage, which separates South America from Antarctica (Rozzi et al. 2017). It is located 60 nautical miles (n.m.) south-west of the Cape Horn archipelago and 430 n.m. north-west of the Antarctic Peninsula, in close proximity to the Antarctic Polar Front. The Diego Ramírez Islands (56 $\left.31^{\prime} \mathrm{S}, 68^{\circ} 44^{\prime} \mathrm{W}\right)$, in particular, and the sub-Antarctic Magellanic ecoregion of extreme southwestern Chile, in general, provide critical breeding habitats for marine mammals and avifauna of global conservation concern, such as the grey-headed albatross (Rozzi et al. 2017). The Diego Ramirez archipelago is the southernmost and one of eight known breeding sites for this species in the world (Fig. 1C). Because of its significance for the conservation of regional biodiversity, the 


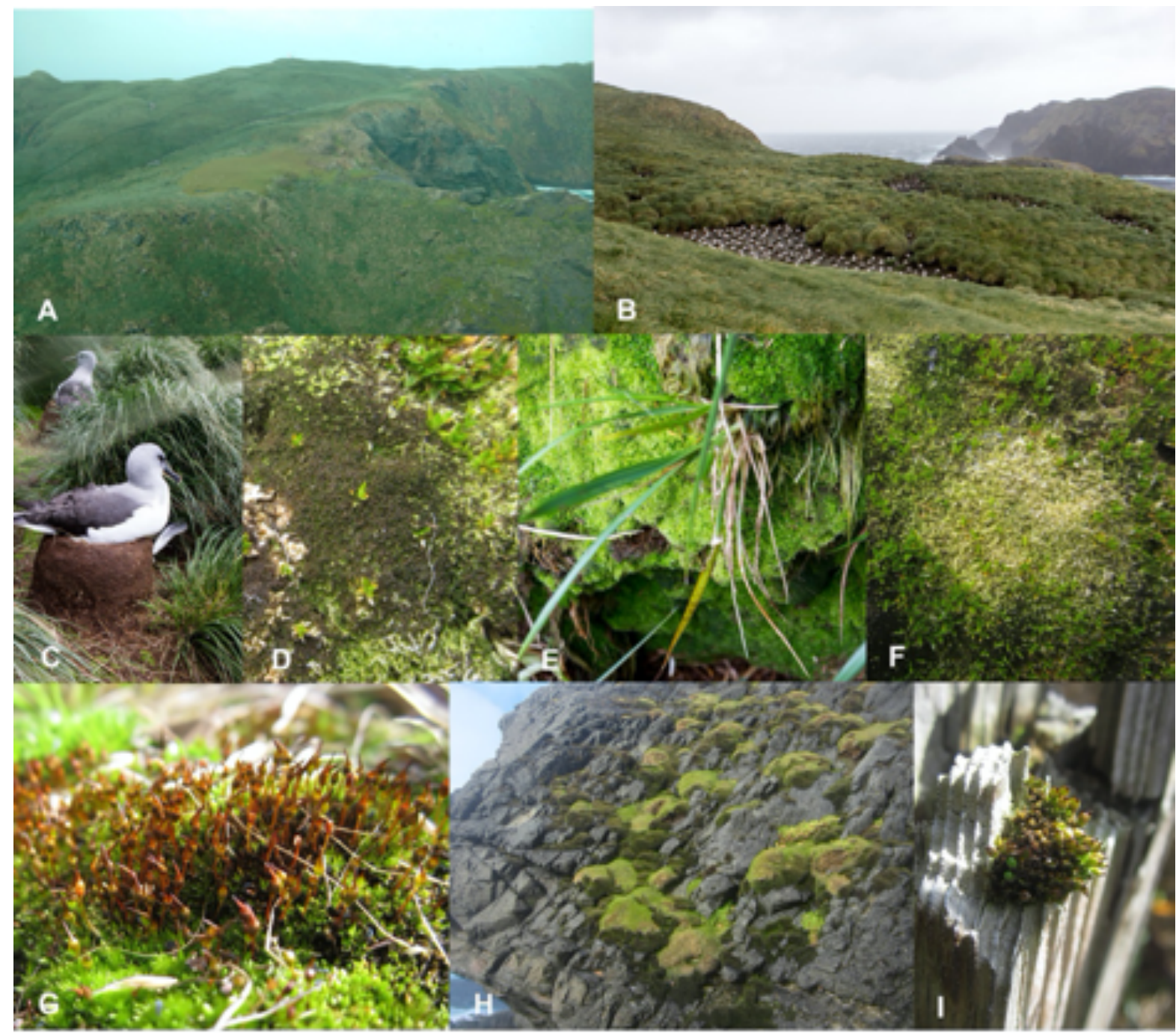

Fig. 1. A. Aerial view of Gonzalo Island, showing the flat summit area surrounded by steep slopes dominated by Poa flabellata. B. Slopes dominated by dense Poa flabellata communities. C. Nesting grey-headed albatross (Thalassarche chrysostoma) at the base of Poa flabellata tussock. D. Cephaloziella dusenii, terricolous. E. Clasmatocolea vermicularis at the base of Poa tussock in the slope. F. Leptoscyphus antarcticus in terricolous vegetation with Colobanthus quitensis. G. Hennediella heimii. H. Steep rock surface near summit colonized by cushion plants and Orthotrichum crassifolium. I.

Orthotrichum crassifolium growing on fence post.

new Diego Ramírez-Drake Passage marine park was recently established (Rozzi et al. 2017). The archipelago was discovered by Europeans in the 17 th century, and only permanently inhabited since mid 20th century by the Chilean Navy following the construction of the lighthouse built on Gonzalo Island.

The vascular vegetation and flora of the Diego Ramírez Islands was described by Pisano (1972) and Pisano \& Schlatter (1981). They documented the presence of eight vascular plants on the two largest islands of the archipelago, Gonzalo and Bartolomé islands. These species are Callitriche antarctica Engelm. ex Hegelm., Cardamine glacialis (Forst. f.) DC, Colobanthus quitensis (Kunth) Bartl., Cotula scariosa (Cass.) Franch., Crassula moschata Forst. f., Plantago barbata Forst. f., Poa flabellata (Lam.) Raspail, and Ranunculus biternatus $\mathrm{Sm}$. The vegetation is largely dominated by Poa flabellata on the slopes (Fig. 1B), whereas 
the rather flat area of the summit is covered by dense communities of Colobanthus quitensis and Plantago barbata (Fig. 1A). Woody plants are entirely absent, and no exotic species have been recorded in the archipelago (see Mackenzie et al. 2020 in this volume). Its floristic affinities are with other Sub-Antarctic islands such as South Georgia, and particularly with the Cape Horn Archipelago (cfr. Pisano, 1980). Additionally, the flora has an affinity with Antarctica since C. quitensis is one of the only two native vascular plants in Antarctica (Komárková et al. 1985). While the vascular flora has been previously studied, the bryophyte flora of Diego Ramírez has remained undescribed until this date, except for the mention of the occurrence of two (unnamed) species of bryophytes in the Colobantho-Plantaginetum vegetation by Pisano and Schlatter (1981).

In past decades, influential assessments of global priorities for conservation have relied on geographic differences in the concentration of diversity and endemism of vertebrates and vascular plants (Myers et al. 2000; Rodrigues et al. 2004; Lamoreux et al. 2006). The majority of publications on plant conservation have focused on vascular flora, and non-vascular plants have remained marginal even at high latitudes where they are the dominant floristic component (Rozzi et al. 2008). Regarding geographical and ecological regions, conservation research is markedly biased to and strongly concentrated in the northern hemisphere (Lawler et al. 2006). In contrast, few studies have investigated patterns of species richness in relation to conservation priorities in sub-Antarctic latitudes, particularly in the sub-Antarctic Magellanic ecoregion of southern South America (Arroyo et al. 2005; Lawler et al. 2006; Rozzi et al. 2012a).

We have attempted to overcome these taxonomic, geographical, and ecoregional biases by moving outside these boundaries, and thereby "change the lenses" that are commonly used to assess regional patterns and conserve biodiversity (Rozzi et al. 2008). In this article, we use these novel "biocultural lenses" (sensu Rozzi et al. 2012b) to include bryophytes for the first-time in the floristic inventory of the southernmost island of the American Continent: Gonzalo Island (56³1'16.8's; 68 42 '53.5' $\mathrm{W}$ ) in the Diego Ramírez Archipelago, Chile.

\section{METHODS}

We examined the specimens of bryophytes collected by Goffinet and Mackenzie on Gonzalo Island during the austral reproductive season, from November 29 to December 1, 2016. For each identified species, we briefly describe the habitat, and provide a summary of its broader geographic distribution.

All vouchers or their duplicates are deposited in the herbarium of the Universidad de Concepción (CONC), which works in partnership with the Institute of Ecology and Biodiversity and the Sub-Antarctic Cape Horn Research Center in Chile, and the herbaria of the University of Connecticut (CONN) or The Field Museum in Chicago $(\mathrm{F})$, in the United States of America. Among the collections, were specimens whose morphological study led to the re-evaluation of the name Lophocolea secundifolia (Hook. f. \& Taylor) Gottsche, Lindenb. \& Nees, for which a new nomenclatural combination is proposed below.

\section{RESULTS}

We identified 14 species of bryophytes on Gonzalo Island, which comprise eight species of liverworts and six species of mosses. Below we provide a concise description for each of the identified species first of (I) liverworts (Division Marchantiophyta), and then of (II) mosses (Division Bryophyta).

\section{Marchantiophyta (liverworts)}

\section{I.1. Cephaloziella dusenii Steph. (Fig. 1D)}

Notes. The status of this species is not unambiguously settled and in particular whether it is distinct from Cephaloziella varians, a bipolar species that occurs in Antarctica (Bednarek-Ochyra et al. 2000), or from the circum-subantarctic $C$. exiliflora (Tayl.) Douin (Engel, 1978).

Ecology. Typically growing among Poa tussocks, also on top of mounds in Colobanthus/ Poa community behind the Navy Station on Gonzalo Island, on abandoned nests.

Distribution. Southern South America, Falkland Islands, and South Georgia; in Chile, it is known from the Valdivian and Magellanic regions (Engel, 1990). 
Specimens seen. B. Goffinet with R. \& Nees, Syn. Hep. 693. 1847. Lectotype (fide Mackenzie 13605 (CONC, F), 13621A (CONC, F), 13624 (F), 13627 (F), 13638 (CONN), 13648 Engel, 1978): Falkland Islands, Hooker (FH!).

Notes. Several authors previously recognized (CONN, F) \& 13661 (CONN, F), Nov. 29-30, this taxon as a distinct species (Gottsche et al. 2016.

I.2. Chiloscyphus secundifolius (Hook. f. \& Taylor) J.J.Engel, comb. nov. (Fig. 2 A-D)

Jungermannia secundifolia Hook. f. \& Taylor, London J. Bot. 3:471. 1844. Lophocolea secundifolia (Hook. f. \& Taylor) Gottsche, Lindenb. 1847; Stephani, 1900, 1906 [1898-1924], 1911; Arnell, 1955), whereas others (e.g. Engel, 1978, 1990; Bednarek-Ochyra et al. 2000; Hässel de Menéndez \& Rubies, 2009) considered it conspecific with Chiloscyphus lentus, which then had an amphipacific distribution, being rather widespread in sub-Antarctic and south temperate areas (e.g. Engel, 1978, 1990). After morphological study of

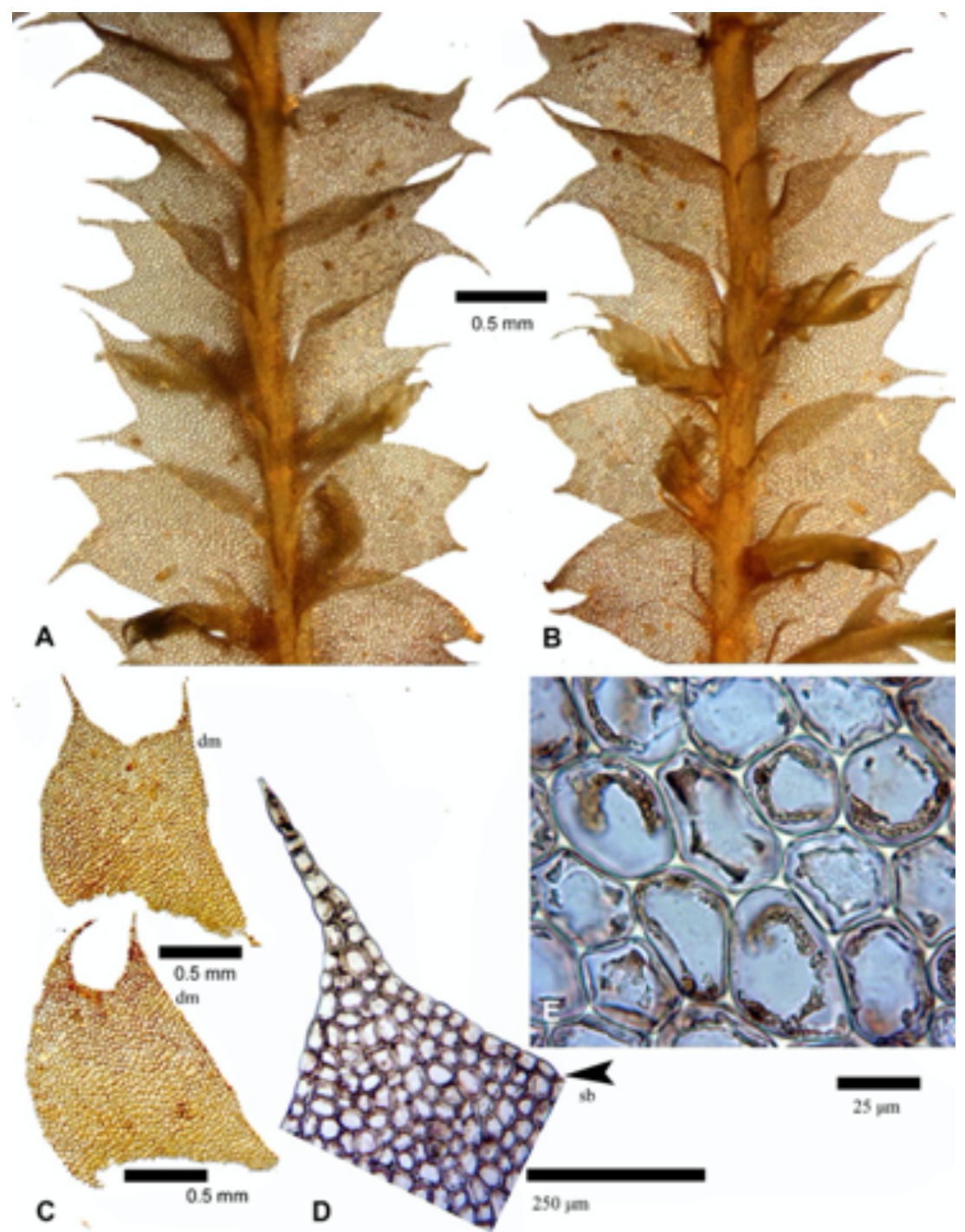

Fig. 2. Chiloscyphus secundifolius (Hook. f. \& Taylor) J.J.Engel. A. Dorsal view, sector of leading shoot (note leaffree strip of stem cells). B. Ventral view, sector of leading shoot (note free underleaves and lateral-intercalary branches).

C. Leaves $(\mathrm{dm}=$ dorsal margin). D. Leaf lobe $(\mathrm{sb}=$ sinus base). E. Median cells of leaf. From Goffinet 13658-F. 
the Australasian members of Chiloscyphus (Engel, 2010), including the type of $C$. lentus, the two taxa are now treated as distinct species. The range of $C$. lentus is now confined to New Zealand (Stewart Is., South Island, North Island) and its offshore islands (Campbell, Auckland and Snares Is.), whereas C. secundifolius is restricted to southern South America and the Falkland Islands.

The species can be distinguished as follows:

\section{Key to Chiloscyphus secundifolius and $C$. lentus}

1. Leaf insertions extending to the stem dorsal midline, no leaf-free strip; underleaves free from leaves but very closely juxtaposed to ventral leaf base on 1 side; plants monoecious; plants terricolous (?always). Southern South America + Falkland Islands .......C. secundifolius

1. Leaf insertions not extending to the stem dorsal midline, delimiting a leaf-free strip of 1 cell; underleaves connate with leaves on 1 side; plants dioecious; plants commonly corticolous. New Zealand (incl. Campbell, Auckland and Snares Islands)

$$
\text { C. lentus }
$$

Ecology. Growing on Poa tussocks as well as on mounds in Colobanthus/Poa community behind the Navy station; at times on tussocks used as bird nests; also on rock of cliff near flagpole.

Distribution. Restricted to southern South America; in the Valdivian and Magellanic regions, Chile, extending eastward to the Falkland Islands, South Sandwich Islands and South Georgia (Grolle, 1972; Longton \& Holdgate, 1979). The report of Lophocolea lenta (Hook. f. \& Taylor) Gottsche, Lindenb. \& Nees from Antarctica in BednarekOchyra et al. (2000) needs confirmation. Lophocolea lenta in the sense of these authors may actually be Chiloscyphus subviridis (e.g. presence of gemmae, leaves sometimes with a tooth, see Bednarek-Ochyra et al., loc. cit. Fig. 74: 1, 6, 8). Without such confirmation, we did not include Antarctica in the distribution of $C$. subviridis.

Specimens seen. B. Goffinet with R. Mackenzie 13621B (CONC, F), 13623 (F) \& 13658 (CONC, CONN, F), Nov. 29-30, 2016.
I.3. Chiloscyphus subviridis (Hook. f. \& Taylor) J.J.Engel \& R.M.Schust.

Notes. Chiloscyphus subviridis produces abundant one- to pluricellular gemmae from the lobes (particularly the tips), the margins, as well as the surface, of leaves. With continued formation of gemmae, the distal sector of the leaf becomes erose and ragged in aspect. Plants also produce regenerants, but to a lesser degree. These modes of asexual reproduction appear to be very efficient; for example, the population of Goffinet 13653 has abundant gemmae and intimately intermixed with mature shoots are copious juvenile shoots in various stages of development. Asexual reproduction by both gemmae and regeneration also occurs in $C$. perpusillus (Hook.f. \& Tayl.) J.J.Engel of New Zealand and Tasmania (see Engel, 1993, 2010). We are unaware of any other species from southern South America with this combination of asexual reproduction.

Ecology. In wet depressions and on mounds in Colobanthus/Poa community behind the Navy station.

Distribution. Southern South America, Falkland Islands; Tristan da Cunha (see Váña \& Engel, 2013); in Chile, from central Chile, and Valdivian regions to the sub-Antarctic Magellanic ecorregion, and westward to Juan Fernández Islands.

Specimens seen. B. Goffinet with R. Mackenzie 13653 (CONN, F) \& 13656 (CONN, F), Nov. 29-30, 2016.

\section{I.4. Chiloscyphus divaricatus (Hook. f. \& Taylor)} J.J.Engel \& R.M.Schust.

Ecology. On base of Poa tussock.

Distribution. Falkland Islands; Magellanic region (Tierra del Fuego, Patagonian Channels in Brunswick Peninsula); Valdivian region (45 $17^{\circ}$ 'S, $\left.73^{\circ} 43^{\prime} \mathrm{W}\right)$.

Specimen seen. B. Goffinet with R. Mackenzie 13608 (CONC, F), Nov. 29-30, 2016.

I.5. Clasmatocolea vermicularis (Lehm.) Grolle (Fig. 1E)

Notes. The Diego Ramirez Archipelago populations on Gonzalo Island differ from typical 
phases of $C$. vermicularis in the abundant Frullania- and (both lateral- and ventral-) intercalary type branches, as well as the bright yellow green or bright green color when dry. Most tufts are compact and comprised of small plants with shoots possessing only a few to several gyres of leaves.

Ecology. On organic material (soil, etc.) on path to Navy station; also on dead Poa tussock. 1990).

Distribution. Pan-south-temperate (Engel,

Specimens seen. B. Goffinet with R. Mackenzie 13604 (CONC, F), 13607 (CONC, F), 13635 (CONN, F), 13636 (CONN, F) \& 13643 (CONN, F), Nov. 29-30, 2016.

I.6. Leptoscyphus antarcticus (C. Massal.) Solari (Fig. 1F)

Notes. This is the sole species of the genus represented on Diego Ramírez. Since Leptoscyphus expansus (Lehm.) Grolle is very common in southern South America (Engel, 1978) and the Falkland Islands (Engel, 1990), one would expect presence of this species, too. Because $L$. antarcticus may be confused with other species of the genus, including L. expansus, a brief description of $L$. antarcticus follows; the description is based solely on material collected on Gonzalo Island.

Plants brittle, green or greyish green or red brown, at times reddish brown in older sectors but lacking pigments distally. Branches of the lateral-intercalary and Frullania types. Leaves with insertion lines not extending to stem midline dorsally, a leaf-free gutter present; leaves usually strongly dorsally assurgent, the adaxial faces of opposing leaves often facing one another, the orientation in some populations variable: some shoots with leaves dorsally assurgent but intermixed are leaves only weakly assurgent, while other shoots have leaves all widely spreading, the leaves weakly convex throughout or slightly concave at the ventral base. Cells with trigones minute. Underleaves ca. 0.75$0.8 \mathrm{X}$ stem width, very narrowly connate on 1 side (by 1 cell), the connation via the underleaf decurrent strip and the extreme base of the leaf margin or by the underleaf decurrent strip and the adaxial face of the leaf base; underleaves widely spreading to reflexed, bifid to $c a$. 0.5-
0.8; lamina on each side with a dentiform to ciliiform process.

Ecology. In somewhat lit niche at the base of Poa tussock, also in Colobanthus/Poa community behind the Navy station.

Distribution. South Georgia; southern South America, Magellanic region (Tierra del Fuego); thus, despite the specific epithet antarcticus, the species is not known from the Antarctic continent (Bednarek-Ochyra et al. 2000).

Specimens seen. B. Goffinet with R. Mackenzie 13637 (CONN, F), 13654 (CONN, F), 13657 (CONN, F) \& 13659 (CONN, F), Nov. 2930, 2016.

I.7. Telaranea plumulosa (Lehm. \& Llindenb.) Fulf.

Ecology. At the base of Poa tussocks.

Distribution. Falkland Islands; southern South America, Valdivian and Magellanic regions, Juan Fernández Islands (Engel \& Smith Merrill, 2004).

Specimen seen. B. Goffinet with R. Mackenzie 13609 (CONC, F), Nov. 29-30, 2016.

\section{I.8. Telaranea pseudozoopsis (Herzog) Fulf.}

Ecology. Growing among tussocks of $P o a$ as well as on the side of living and dead Poa tussocks.

Distribution. Southern South America, Valdivian and Magellanic regions, Falkland Islands (Engel \& Smith Merrill, 2004).

Specimens seen. B. Goffinet with R. Mackenzie 13626 (F), 13645 (CONN, F) \& 13660 (CONC, CONN, F, NY), Nov. 29-30, 2016.

\section{Bryophyta (mosses)}

\section{II.1. Amblystegium serpens (Hedw.) Schimp.}

Ecology. In cushion plant community; elsewhere known from a variety of habitats, such a decaying wood, rocks, in wet to xeric habitats (Vanderpoorten, 2014).

Distribution. Virtually cosmopolitan (Vanderpoorten, 2014); in Chile, primarily known from central regions (i.e., Coquimbo to Bío-Bío; He, 1998), but also found in Juan Fernández 
Islands (Robinson, 1975); not yet known from the Magellanic region, including the well explored, Navarino Island (Buck \& Goffinet, 2010), but reported from the Falkland Islands (Robinson, 1975). New to sub-Antarctic Chile.

Specimen examined. B. Goffinet with R. Mackenzie 13641 (CONC, CONN, NY).

\section{II.2. Bryum orbiculatifolium Cardot \& Broth.}

Notes. This species is distinguished by its small size, deeply concave and imbricate leaves that are typically rounded obtuse (Ochyra et al. 2008, also treated as Plagiobryoides orbiculatifolia (Cardot \& Broth.) Ochyra \& Bedn.-Ochyra; see Ochyra \& Bednarek-Ochyra, 2017). It has been confused with forms of the rather highly variable Bryum pseudotriquetrum, whose leaves are, however, reddish at the base, and typically decurrent. The material attributed here to $B$. orbiculatifolium, lacks decurrencies and the lamina is green throughout. The leaves are strongly concave, densely imbricate especially toward to the apex, and the leaf apex is rather obtuse and apiculate, similar to some Antarctic plants (Ochyra et al. 2008).

Ecology. On compact soil with Hennediella in summit vegetation, and along path near Navy station.

Distribution. Southern temperate amphiAtlantic (Ochyra et al . 2008); Diego Ramírez Islands may mark the western limit of its distribution.

Specimens examined. B. Goffinet with R. Mackenzie 13684 (CONN), s.n. releve 2 (CONC), Nov. 29-30, 2016.

II.3. Bryum pseudotriquetrum (Hedw.) G. Gaertn., B. Mey. \& Scherb.

Ecology. Base of seepage, on outcrop close to Navy station; overall rather ubiquitous, typically terricolous, but also on rocks and gravel, and rarely aquatic (Ochyra et al. 2008).

Distribution. Transequatorial, with occurrences at high altitudes in tropical latitudes; widespread in both northern and southern hemispheres, including across all sub-Antarctic islands (Ochyra et al. 2008).

Specimen examined. B. Goffinet with R. Mackenzie 13664 (CONN), Nov. 29-30, 2016.
II.4. Calyptrochaeta apiculata (Hook. f. \& Wilson) Vitt

Ecology. On soil, in wet, community behind the Navy station; elsewhere on soil along creeks, low epiphyte on shrubs and tree ferns, decaying logs, and on wet rocks (Pokorny et al. 2011).

Distribution. Austral (Pokorny et al. 2011), with disjunct occurrences in Southern South America, including Falkland Islands and Navarino Island (Buck \& Goffinet, 2010), SE Australasia and Marion Island (South Africa); in Chile known from the Valdivian region southward.

Specimens examined. B. Goffinet with R. Mackenzie 13647 (CONC, CONN), 13650 (CONC, CONN) \& 13652 (CONN, NY), Nov. 2930, 2016.

II.5. Hennediella heimii (Hedw.) Zander (Fig. 1G)

Ecology. On soil, along path, or in cushion plant vegetation at summit; elsewhere also terricolous, considered a halophyte, although not restricted to salt enriched substrates.

Distribution. Strictly bipolar, widespread in the Northern Hemisphere and with an austral distribution in the Southern Hemisphere (Ochyra et al. 2008).

Specimen examined. B. Goffinet with R. Mackenzie 13642a (CONN), Nov. 29-30, 2016.

II.6. Orthotrichum crassifolium Hook. f. \& Wilson (Fig. 1H, I)

Notes. This species was formerly accommodated in the genus Muelleriella Dusén (Vitt, 1976) until phylogenetic evidence revealed that this clade of austral species was nested within the cosmopolitan genus Orthotrichum (Goffinet et al. 2004). Orthotrichum crassifolium and its close relatives (i.e. Muelleriella sensu Vitt) are in part characterized by their multicellular spores (Vitt, 1976).

Ecology. Halophyte or at least halotolerant, typically growing on rocks from sea-level to the summit, with cushion plants and occasionally with the lichen Ramalina terebrata Hook. f. \& Taylor (Goffinet with Mackenzie 13632, CONC); recorded once from a fence post (Goffinet with 
Mackenzie 13674); elsewhere also on rocks mostly at sea level.

Distribution. Circumsubantarctic, including southernmost South America, and New Zealand (Ochyra et al. 2008; Vitt, 1976; as Muelleriella crassifolia (Hook. f. \& Wilson) Dusén).

Specimens examined. B. Goffinet with R. Mackenzie 13663 (CONN), 13674 (CONN), 13687 (CAS, CONC, CONN, NY) \& 13688 (CONC, CONN), Nov. 29-30, 2016.

\section{DISCUSSION}

The bryophyte flora of Gonzalo Island in the Diego Ramírez archipelago comprises 14 species, eight liverworts and six mosses. This number of non-vascular species nearly doubles the number of vascular plants present on the island (Mackenzie et al. 2020, in this volume). The non-vascular/vascular $(\mathrm{NV} / \mathrm{V})$ plant species ratio is 1.75 . This value is seven times higher than the average $\mathrm{NV} / \mathrm{V}$ ratio of 0.25 for Chile, and even $66 \%$ higher than the $\mathrm{NV} / \mathrm{V}$ ratio of 1.05 for the rest of the sub-Antarctic Magellanic ecoregion in southern Chile (see Rozzi et al. 2008). Consequently, our study contributes to fill a critical knowledge gap regarding the flora of the Diego Ramírez archipelago, and establishes a comprehensive floristic characterization of this deep southern ocean archipelago for longterm socio-ecological research and biocultural conservation (sensu Rozzi et al. 2006).

The small size of Gonzalo Island combined with its low altitude exposes much of the surface to intense salt spray that may limit the colonization of the island by additional bryophytes. The flora most conspicuously lacks thalloid liverworts (such as Marchantia berteroana Lehm. \& Lindenb.), and any Sphagnum species, which are both abundant in coastal vegetation on Horn Island and other islands of the archipelago (Goffinet \& Rozzi, pers. obs.). None of the liverwort species showed signs of sexual reproduction (i.e. no gametangia or sporophyte seen; the only exception being young gynoecia in Leptoscyphus antarcticus), whereas at least two mosses (i.e. Hennediella heimii and Orthotrichum crassifolium) develop numerous sporophytes. As for specialized asexual reproductive structures, only Chiloscyphus subviridis produces gemmae.
All species, except Amblystegium serpens, are known to occur in the sub-Antarctic Magellanic ecoregion (Buck pers. com.), and only four, all mosses, occur also on the Antarctic continent (Ochyra et al. 2008). Although A. serpens is here newly recorded for the sub-Antarctic Magellanic ecoregion from where is it so far unknown (William Buck pers. com. 12 April 2018), it was known from the Falkland Islands, central Chile, and the Juan Fernández Islands (Robinson, 1975), and hence its presence in the Magellanic region is to be expected.

The dominant part of the bryophyte flora of the Diego Ramírez archipelago, and in particular its liverwort component, exhibits strong affinities with the flora of continental and maritime (sub) Antarctic (e.g. Bednarek-Ochyra et al. 2000; Ochyra et al. 2008) and oceanic islands such the south temperate Falkland Islands, subtropical Tristan da Cunha, and the cool-temperate Gough Island and New Zealand's shelf islands (Vitt, 1976; Engel, 1990; Engel \& Glenny, 2008, 2019a, 2019b; Váña \& Engel, 2013).

Patterns of floristic similarities based on seedless plants among austral regions of the world may be shaped by geographic distance between areas, but also by the positions of these areas relative to the path of major ocean surface wind currents (Muñoz et al. 2004). Current wind connectivity, as well as geographic distances, would suggest that the flora of Diego Ramírez islands should share much (or all) of its flora with the nearby Cape Horn Archipelago, and perhaps with the Antarctic Peninsula, except that the islands are located west of these areas and hence implied dispersal would be against the predominant westerly winds (i.e. west to east). The island hosts an extensive breeding colony of the grey-headed albatross (Thalassarche chrysostoma (Forster, 1785; Robertson et al. 2007), a bird that moves freely across the austral region. Although this bird could theoretically act as a dispersal vector between islands, its feeding behavior, which consists of diving for marine prey (Arata et al. 2004), makes this unlikely. Phylogeographic analyses of the species occurring on Diego Ramírez based on extensive population sampling from across their range in austral regions, may be the sole approach to determine the source of dispersal to Diego Ramírez, and perhaps the 
role and potential of the island as a source for the colonization of Antarctica.

Finally, none of the bryophyte species recorded on Gonzalo Island is exotic, but Calyptrochaeta apiculata was only found in a small wet herbaceous community immediately behind the meteorological station. Our study provides a critical baseline for the southernmost Long-Term Socio-Ecological Research (LTSER) site of the Chilean LTSER network (see Rozzi et al. 2020, in this volume).

\section{ACKNOWLEDGEMENTS}

We wish to thank our colleagues at the Field Museum, Anders Hagborg for advice on locality data and Yarency Rodríguez for general assistance, anonymous reviewers, and Dr. Juan Armesto for valuable comments on the manuscript. Dr. William Buck (New York Botanical Garden) kindly identified the specimen of Amblystegium serpens. This work had the support of ANID-PAI 79170119, Apoyo a Centros Científicos y Tecnológicos de Excelencia, Financiamiento Basal ANID-AFB170008 to Institute of Ecology and Biodiversity (IEB-Chile), and the Mar y Tierra Work Group of The Pew Charitable Trust, Omora Foundation, in Chile. It is a contribution of the Sub-Antarctic Biocultural Conservation Program, jointly coordinated by IEBand the University of Magallanes in Chile, and the University of North Texas in the USA.

\section{LITERATURE CITED}

Arata, J., Robertson, G., Valencia, J., Xavier, J. C., \& Moreno, C. A. (2004). Diet of greyheaded albatrosses at the Diego Ramírez Islands, Chile: ecological implications. Antarctic Science, 16, 263-275.

Arnell, S. (1955). Hepaticae of Chile and Argentina collected by R. Santesson. Suensk Botanisk Tidskrift, 49, 229-239.

Arroyo, M. T. K., Mihoc, M., Pliscoff, P., \& Arroyo-Kalin, M. (2005). The Magellanic moorland. In L. Fraser \& P. Keddy (Eds). The world's largest wetlands. Cambridge, UK: Cambridge University Press.

Bednarek-Ochyra, H., Váña, J., Ochyra, R., \& Lewis Smith, R. I. (2000). The liverwort flora of Antarctica. Polish Academy of Sciences, Institute of Botany, Cracow, Poland.

Buck, W. R., \& Goffinet, B. (2010). Preliminary key to the mosses of Isla Navarino, Chile (Prov. Antártica Chilena). Beihefte zur Nova Hedwigia, 138, 215-229.

Chown, S., Gremmen, N., \& Gaston, K. (1998). Ecological biogeography of Southern Ocean Islands: species-area relationships, human impacts, and conservation. The American Naturalist, 152, 562-575.

Engel, J. J. (1978). A taxonomic and phytogeographic study of Brunswick Peninsula (Strait of Magellan) Hepaticae and Anthocerotae. Fieldiana, Botany, 41, i-viii, $1-319$.

Engel, J. J. (1990). Falkland Island (Islas Malvinas) Hepaticae and Anthocerotae: A taxonomic and phytogeographic study. Fieldiana, Botany N.S., 25, i-viii, 1-209, figs. 1-88.

Engel, J. J. (1993). Studies on Geocalycaceae (Hepaticae). IX. Chiloscyphus perpusillus (Hook. f. \& Tayl.) Engel. A study in novel asexual reproductive strategies. Nova Hedwigia, 56, 241-246, f. 1-2.

Engel, J. J. (2010). Austral Hepaticae 45. A monograph of the genus Chiloscyphus Corda (Lophocoleaceae) for Australasia. Fieldiana, Botany N.S., 48, i-vi, 1-209, f. $1-81$.

Engel, J. J., \& Smith Merrill, G. L. (2004). Telaranea Austral Hepaticae. 35. A taxonomic and phylogenetic study of Telaranea (Lepidoziaceae), with a monograph of the genus in temperate Australasia and commentary on extra-Australasian taxa. Fieldiana Botany 44, i-iv, 1-265, f. 1-86, tab. 1-4.

Engel, J. J., \& Glenny, D. (2008). A flora of the liverworts and hornworts of New Zealand. Vol. 1. Monographs in Systematic Botany 110, 1-897, f. 1-177.

Engel, J. J., \& Glenny, D. (2019a). A flora of the liverworts and hornworts of New Zealand. Vol. 2. Monographs in Systematic Botany 134, 1-739, f. 1-221.

Engel, J. J., \& Glenny, D. (2019b). A flora of the liverworts and hornworts of New Zealand. 
Vol. 3. Monographs in Systematic Botany 135, 1-636, f. 1-167.

Goffinet, B., Shaw, A. J., Cox, C. J., Wickett, N. J., \& Boles, S. (2004). Phylogenetic inferences in the Orthotrichoideae (Orthotrichaceae: Bryophyta) based on variation in four loci from all genomes. Monographs in Systematic Botany from the Missouri Botanical Garden, 98, 270-289.

Gottsche, C. M., Lindenbergm, J. B. G., \& Nees von Esenbeck, C. G. (1844-1847). Synopsis Hepaticarum. Meissner, Hamburg, pp. 1-834. (Fasc. I, pp. 1-144, 1844; Fasc. IIIII, pp. 145-464, 1845; Fasc. IV, pp. 465624, 1846; Fasc. V, pp. 625-834, 1847).

Grolle, R. (1972). The hepatics of the South Sandwich Islands and South Georgia. British Antarctic Survey Bulletin, 28, 83-95.

Hässel de Menéndez, G. G., \& Rubies, M. F. (2009). Catalogue of Marchantiophyta and Anthocerotophyta of southern South America. Beihefte zur Nova Hedwigia, 134, 1-672.

He, S. (1998). A checklist of the mosses of Chile. The Journal of the Hattori Botanical Laboratory, 85, 103-189.

Komárková, V., Poncet, S., \& Poncet, J. (1985). Two native Antarctic vascular plants, Deschampsia antarctica and Colobanthus quitensis: a new Southernmost locality and other localities in the Antarctic Peninsula Area. Arctic and Alpine Research, 17, 401-416.

Lamoreux, J. F., Morrison, J. C., Ricketts, T. H., Olson, D. M., Dinerstein, E., McKnight, M. W., \& Shugart, H. H. (2006). Global tests of biodiversity concordance and the importance of endemism. Nature, 440, 212-214.

Lawler, J. J., Aukema, J. E., Grant, J. B., Halpern, B. S., Kareiva, P., Nelson, C. R., Ohleth, K., Olden, J. D., Schlaepfer, M. A., Silliman, B. R., \& Zaradic, P. (2006). Conservation science: a 20-year report card. Frontiers in Ecology and the Environment, 4, 473480.

Longton, R. E., \& Holdgate, M. W. (1979). The South Sandwich Islands: IV. Botany. British Antarctic Survey Scientific Reports, 94, 1-53.
Mackenzie, R., Vidal, O., Rosenfeld, S., Contador, T., Barroso, O., Goffinet, B., Massardo, F., Arce-Johnson, P., \& Rozzi, R. (2020). Flora Vascular y Formaciones Vegetacionales en el Sitio de Estudios Socio-Ecológicos a Largo Plazo, Isla Gonzalo, Archipiélago Diego Ramírez (56 $31^{\circ}$ 's), Chile. Anales del Instituto de la Patagonia, 48, Accepted.

Muñoz, J., Felicísimo, Á. M., Cabezas, F., Burgaz, A. R., \& Martínez, I. (2004). Wind as a longdistance dispersal vehicle in the Southern Hemisphere. Science, 304, 1144-1147.

Myers, N., Mittermeier, R. A., Mittermeier, C. G., Da Fonseca, G. A., \& Kent, J. (2000). Biodiversity hotspots for conservation priorities. Nature, 403, 853-858.

Ochyra, R., Lewis Smith, R.I., \& Bednarek-Ochyra, H. (2008). The illustrated moss flora of Antarctica. Cambridge, UK: Cambridge University Press.

Ochyra, R., \& Bednarek-Ochyra, H. (2017). Nomenclatural novelties in the Bryaceae (Bryophyta). Polish Botanical Journal, 62, 169-173

Pisano, E. (1972). Observaciones fito-ecológicas en las islas Diego Ramírez. Anales del Instituto de la Patagonia, Serie Ciencias Naturales, 3, 161-169.

Pisano, E. (1980). Catálogo de la flora vascular del Archipiélago del Cabo de Hornos. Anales del Instituto de la Patagonia, Serie Ciencias Naturales, 11, 151-189.

Pisano, E., \& Schlatter, R.P. (1981). Vegetación y flora de las islas Diego Ramírez (Chile). 1. Características y relaciones de la flora vascular. Anales del Instituto de la Patagonia, 12, 183-194.

Pokorny, L., Oliván, G., \& Shaw, A. J. (2011). Phylogeographic patterns in two southern hemisphere species of Calyptrochaeta (Daltoniaceae, Bryophyta). Systematic Botany, 36, 542-553.

Robertson, G., Moreno, C. A., Lawton, K., Arata, J., Valencia, J., \& Kirkwood, R. (2007). An estimate of the population sizes of Blackbrowed (Thalassarche melanophris) and Grey-headed (T. chrysostoma) albatrosses breeding in the Diego Ramírez Archipelago, Chile. Emu, 107, 239-244. 
Robinson, H. E. (1975). The mosses of Juan Fernández Islands. Smithsonian Contributions to Botany, 27, 1-88.

Rodrigues, A. S., Andelman, S. J., Bakarr, M. I., Boitani, L., Brooks, T. M., Cowling, R. M., Fishpool, L. D., Da Fonseca, G. A., Gaston, K. J., Hoffmann, M., \& Long, J. S. (2004). Effectiveness of the global protected area network in representing species diversity. Nature, 428, 640-643.

Rozzi, R., Massardo, F., Anderson, C., Heidinger, K., \& Silander, J. (2006). Ten principles for biocultural conservation at the southern tip of the Americas: the approach of the Omora Ethnobotanical Park. Ecol Soc 11, 43. http://www.ecologyandsociety.org/ vol11/iss1/art43/.

Rozzi, R., Armesto, J., Goffinet, B., Buck, W. R., Massardo, F., Silander, J., Kalin-Arroyo, M., Russell, S., Anderson, C., Cavieres, L., \& Callicott, J. (2008). Changing biodiversity conservation lenses: insights from the subAntarctic non-vascular flora of southern South America. Frontiers in Ecology and the Environment, 6, 131-137.

Rozzi, R., Armesto, J. J., Gutiérrez, J., Massardo, F., Likens, G., Anderson, C. B., Poole, A., Moses, K., Hargrove, G., Mansilla, A., Kennedy, J. H., Willson, M., Jax, K., Jones, C., Callicott, J. B., \& Kalin-Arroyo M. T. (2012a). Integrating ecology and environmental ethics: Earth stewardship in the southern end of the Americas. BioScience, 62(3), 226-236.

Rozzi, R., Lewis, L., Massardo, F., Medina, Y., Moses, K., Méndez, M., Sancho, L., Vezzani, P., Russell, S., \& Goffinet, B. (2012b). Ecotourism with a hand-lens at Omora Park. Punta Arenas: Ediciones Universidad de Magallanes.

Rozzi, R., Massardo, F., Mansilla, A., Squeo, F. A., Barros, E., Contador, T., Frangópulos, M., Poulin, E., Rosenfeld, S., Goffinet, B., González-Weaver, C., Mackenzie, R., Crego,
R. D., Viddi, F., Naretto, J., Gallardo, M.

R., Jiménez, J.E., Marambio, J., Pérez,

C., Rodríguez, J.P., Méndez, F., Barroso,

O., Rendoll, J., Schüttler, E., Kennedy, J.,

Convey, P., Russell, S., Berchez, F., Sumida,

P. Y. G., Rundell, P., Rozzi, A., Armesto, J., Kalin-Arroyo, M., \& Martinic, M. (2017). Parque Marino Cabo de HornosDiego Ramírez. Programa de Conservación Biocultural Subantártica, Punta Arenas, Chile: Ediciones Universidad de Magallanes.

Rozzi, R., Crego, R. D., Contador, T., Schüttler, E., Rosenfeld, S... \& Massardo, F. (2020). Un centinela para el monitoreo del cambio climático y su impacto sobre la biodiversidad en la cumbre austral de América: la nueva red de estudios socio-ecológicos a largo plazo Cabo de Hornos. Anales del Instituto de la Patagonia, 48, Accepted.

Stephani, F. (1898-1924). Species Hepaticarum. 6 vols. Geneva \& Bale.

Stephani, F. (1900). Beiträge zur Lebermoosflora Westpatagoniens und des Südlichen Chile. Bihang till Kongliga vetenskapsakademiens handlingar, 26 (III, 6), 1-69.

Stephani, F. (1911). II. Die Lebermoose. In C. Skottsberg (Ed.), Botanische Ergebnisse der Schwedischen Expedition nach Patagonien und dem Feuerland 1907-1909. Kongliga vetenskaps-akademiens handlingar, 46(9), 1-92, f. 1-35.

Váña, J., \& Engel, J. J. (2013). The liverworts and hornworts of the Tristan da Cunha Group of Islands in the South Atlantic Ocean. Memoirs of the New York Bot. Garden 105, i-x, 1-138, Figs. 1-11.

Vanderpoorten, A. (2014). Amblystegium. In Flora of North America Editorial Committee (Ed.), Flora of North America, North of Mexico. Volume 28. Bryophyta, Part 2. (p. 301). New York: Oxford University Press.

Vitt, D. H. (1976). A monograph of the genus Muelleriella Dusén. Journal of the Hattori Botanical Laboratory, 40, 91-113. 